Unjtad States

Departwant of the Intorior

Goologica], Survey

Washsington

\title{
Geologer Investigations
}

Naval Petrolousn Roserve No. 4

Alestea

\section{U. S. Geological Survey OPEN FILE REPORT}

This report is preliminary and has not been edited or reviewed for. conformity with Geological Survey standards or nomenclature.

Spocial Hapost 40

PROGRESS REPORT ON THE KIUIGIAA ANTICLINORIUM

By

Irvia Lo Tailleur and Bion $\mathrm{H}_{0}$ Kent 
Page

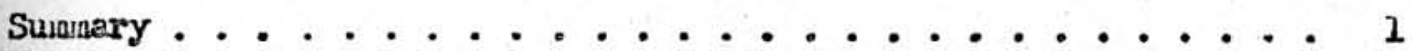

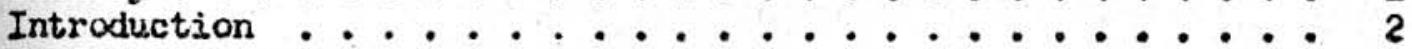

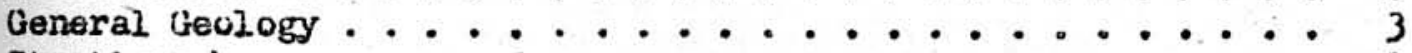

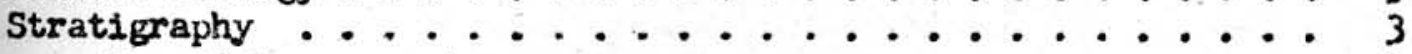

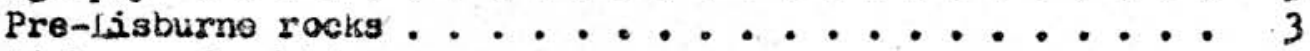

Lisburne formation .............. 3

Minor lithologic types ........... 5

Post Lisburne, pre-fur ois units .......... 5

Okpiksuak fornation (Lowar Crstacecus) . . . . . 6

Castio Mountain-Tor ok formations (Lonsr Cretsceous). . . 6

Nanushulk group (Lower and Upper Lreteceous) ......

Structure ................... 8

Tho srady anticline ..................... II

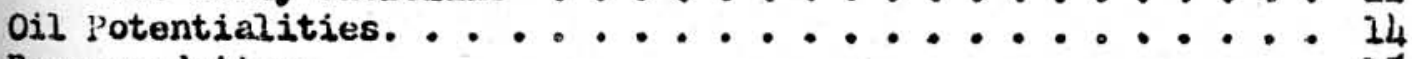

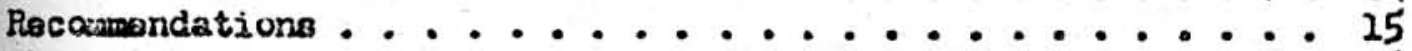

Photogeologic obsarvations on the irady anticline...... 16

Stratigraphy ................. 16

structure. . . . . . . . . . . . 36

\title{
THLUSTRATIONS
}

Table 1. Estinated noriaal etratigraphic section on the brady anticline

(1)




\section{PROCRESS REPORT ON THE KCLIOITA ARTICLINORIUSA}

by

Irvin Lo Tuilleur and Bion $\mathrm{H}_{0}$ Kemt

\section{SUEA HARP}

Th1s report was propared to agsist in the planning of seisinic proPiles to be run across the anticlinorium in the vicinity of the Kiligwa River. The stratigraphy and structure of the mapped eree south of the anticlinorium are reviened. Two facies of the Lisburne formation, a calcarenito-hydroclastic limastone facies and a black shale, black chert and dark limestone facies, have been distinguished. In the scuthern foothills, the black shale facies appears to have been thrust from the soith over the limestone facies. The available evidence indicates that the liaburne formation, as linnestone or a more praximal facies was deposited wor the area of the anticlinorium. Following a redefinstion of the Torok formation in the type area, strata formorly mapped as I'orok have here been designated Castle Mountain formation. The depositional history of the Castle ilountain fornation reflects active orogeny. Lonses of coarse clastics appear to heve been dumped in 2ocal basins; equivalent beds to the north are uach finer. A basal zone of sandstone mey be more extensive and may correlate with the sandstones noted along and north of the anticlinoriurs.

She flat thrusto dorisate the foothills structure and the displaceo mants on theis may bo in the order of several miles. Unconformities are locally present under nost of the post-inisburne units. The major deformation began in the Jurassic and contimed eparmodically into Albian tiune. At the Liborator Ridges, the Castle Nountain formation overlies Shublik (Triassic formation); at Ekakevik Mountain, avveral thousend feet of foldod Castle Mountain formation ase mising uncler the upperinost Castle Hountain strata.

Okpiloruak fossils have boen identified from the axis of the Brady anticline on the Kiligwa Kiver. The structure and lithology there indicate an anticline a few hundred feet vide. There is evidence of foulting on the north linb. Information fron the Killywa and Ipnavik Bivers indicate that lower strata of the Castle Nountain formution are present along the axis of the anticlinorium, supporting the eupposition that a structural high is prosont batwoen the north dipping beds at Lookout Ridge and south dipping beds along the north margin of the foothills complex. Traces and other evidence of lineation on photographs show an apparent convergence away frorn the chanize in strike of the anticlinorium in the area of the Kiligwa-Nuka Hivers which may indicate plunge away from the area of bowing. 
Of the many possible atructural situations that vould fit the scanty cata avajlable, the foll, wring aro believed to be the inost likely to occur: 1) the Bracy antichine is on the crestal area of a broad arch in the basement (Iteburme formation); 2) the Brady antalcine is the ourface expression of a thrust fault in the basenent, analagous to Albertan foothills etructures; 3) the relatively incorapetent poetolieburne beds have baen crunpled by decollement folding on a comparatively Mat, coupatert basenent. Surface evidence is not definitive and the aub-Burface structure will have to be determined by other methoda such as seismic studies or by drilling.

An estirated 3,600-5,000 feot of section would normally overitie the Lisburne formation at the Brady anticline, and would consist of $1,500-2,000$ feet of Okpikruak shale and siltstone, $1,500-2,000$ feet of Jurassic shale, 300 feet of Trisosic shale and limestone, and $300-600$ feet of Carboniforous-Perilian shale and chexto. It should be notod that these figures are ressonable eatjuntes besed on the information avail able.

Proposed seismic profiles are shorn on the geologic uap. They are designed to test the subsurface locally ato the Brady antilcline and also the subsurface cver the breador area of the bowing of the anticlinorius. The apical aros of the boring, in the vicinsty of the Nuka Kiver, appears more promiajng from regicnal vievposint than the Brady anticline and ahould be prospected for an adoquate evaluation of the anticlinoriun trend and regjomel high. However pre-Castle Mountain beds, the oldest beds along the trend, are exposed at the Brady antseline and therefore this structure has boen selacted for the initial test.

\section{ZMTRODHCIOA}

Scheduled seisulc and drilling activity within the Kiligwaonuka Rivers axsa nakss $a$ jrogress report on the evaluation of field data pertinerit. The information presented in Preliminary Report 37 (Kiligwa River area, 1951) hes been revised and reinterpreted.

The authors have spent much of the pest year's gart--time employment with the U. So Ceological Survey synthesining a logical stratigrajhic and structural picture of the Cast 10 siountain-Torok formations. Field date were analyzed and photographs were studied to couplenent and to add to field infurination. These investigations, horaver, have not yieided any conclusive reoults because the originil mapping scale was too subil to perinit the dosired largessale, dotailed interpretations. The fol lowing observations and conclusions are therefore speculative. They are the result of converging lines of evidence or the most logical explanation, in the light of ous experience, of observed facts. In order that the reader may indepondently ovalutite the conclusions, objective data will be distinguighed from subjective ovidence and personal inapessions ar opinions. 
The objective of the recent atudias hes been to locate a drilizing aite that would test the Lisburne formation in the Etiviuk-Nuka Rivers area. The controlling factors are: (1) that the location be close enough to cutcrops of Ijisburno f ormation to warrant the assumption that it will be present in the subsurfaca; (2) that the location have reasonable (estimated depth to the Ijisburne; (3) that tho location be fax enough north to be cut of the ares of extreme etructural complexity; (4) thiat the location have iavorable oubsurface structure. No locality is idesily situsted with respect to these factors. The best sits in the area studied is on the parady anticline where it is cut by the Kiligwa River。

The Brady anticline 2 is 17 miles north of outcrops of Lisbume formation. It lies near the axis of an anticlinordum or broad dip reversal Wich is indiested by couth-dipping beds to the south and younger, northdipping beds to the north. In this report this major structure is reforred to as tho "Kiligwa anticlinorius". Aucella sublasvis Keyserling, restricted to the Okpikruak formation as far as known, has been identified from beds on the Brady anticlinal axis, indicating that if the underlying strate is in nosmal sequence only a fer thousand feet of bection overlies the lisburne formation. The local structural complexity cannot bo determined. The only perinissible observation is that tho Brady anticline is 8 to 9 miles now th of intensely cleformed competent beds and 17 miles north of recognizable flat thrusts.

\section{STRATTGRAPHY}

Pre-Lisburne rocks. - A zinostone combeining Uppar Devonian fossils 1s associated with the thrust plates that corapsise the eaviorn end of the DeLong Wountains. It crops out disectly below a limestone unit 11thologically sirailar to the Lisburne formition and appoars to form the sole of the thrust sheets. This Dovonian limestone has biostromal aspects in one exposure on the eouth side of the Delong Mountains, oppoaite the headwaters of the Jast and Hest Forics of the Kiligwa Kiver. No prediction of its presence in the Brady area can be made.

The Kanayut-Kayak (Davonian-iliesiasippian) strata forming the front ridges of the srooks lange at the heatwaters of the kuna River plunge out to the west and are not present in the Delong Mountains. Outerops on the north side of tho Delong Hountains, at the head of the jast Fork of the Kilisgre Kiver, insy bo oquivalent to the Kayak formation but contained fossils have yet to be identified. No speculation on the northerly projuction of the Kamayut-Kavats forrsations is warranted.

Lisburne formation. Seweral lithologic units of the lisburne for-

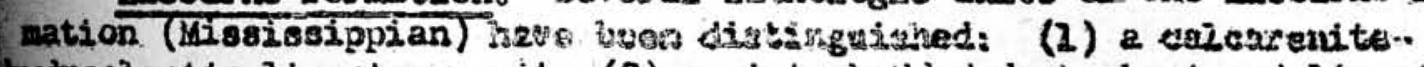
hydroclastic linsetone unit; . (2) an interbodded dark chert and limestone unt; (3) a black shale, bleck chart and dark limestone umito 


\section{Table 1. Lstixated normill. Gisetigraphic sectjon on the Exedy anticline}

\begin{tabular}{|c|c|c|c|}
\hline $\begin{array}{l}\text { Stratigraphi.c } \\
\text { unit }\end{array}$ & $\begin{array}{c}\text { Thickness } \\
\text { (roet) } \\
\end{array}$ & $\begin{array}{l}\text { Composikion } \\
\text { Isthology }\end{array}$ & $\begin{array}{l}\text { Depth to top } \\
\text { (feet) }\end{array}$ \\
\hline $\begin{array}{l}\text { Olspikmual } \\
\text { fornation }\end{array}$ & $1,500-2,000$ & $\begin{array}{c}\text { Shalo (siltio } \\
\text { stone) }\end{array}$ & 0 \\
\hline $\begin{array}{l}\text { Jurassic } \\
\text { (Tiglukpuk } \\
\text { foriation) * }\end{array}$ & $1,500-2,000$ & Shale & $1,500-2,000$ \\
\hline $\begin{array}{l}\text { Triassic } \\
\text { (Shublik } \\
\text { forination) }\end{array}$ & 300 & $\begin{array}{l}\text { Lirnestione } \\
\text { and shaj.e }\end{array}$ & $3,000-4,000$ \\
\hline $\begin{array}{l}\text { Carboniferous- } \\
\text { Permian (Sik- } \\
\text { sikpuk for- } \\
\text { mation) }\end{array}$ & $300-600$ & $\begin{array}{l}\text { Shele, ininur } \\
\text { chert }\end{array}$ & $3,300-4,300$ \\
\hline $\begin{array}{l}\text { Lisburne } \\
\text { formation }\end{array}$ & $?$ & $\begin{array}{l}\text { Limestune, } \\
\text { possibly } \\
\text { sandstorwe }\end{array}$ & $3,600-4,900$ \\
\hline
\end{tabular}

Tiglukpak formation includies all Jurassic age strała in central brooks hange region. 
(2) The 1ithologic charactorigtics of the Lisburne formation at the Lisburne Kidges and at lit. Eupto dsecribed in Rojort 43 is axe aimilar to sections of bydroclastic jinestons exposed in the Brooks Range farther aast. Thin diabase $\$ i l l 3$ have intruded the Lisburne formation et the Lisburns Ridgos but are not present at ut. Bupto. Two sones of black shale and black cher's sirailar to the strata of the Klruktegiak member occus in the Mio nupto section; siniler strata cap the limestons on the Hidges.

(2) Lisburne strate on the Ipnavik thrust sheet are compcesed of irregulariy interbedded limestone and chert. Similariy interbedded chert and limestone occur in the Dolong Mountains thrust shoets. Both sections hava bsen intruded by mafic sills and now crop out in broad aynclinal etructures, resulting in zevarse topography. In cuntirest, 14. Bupto appears to have boen pushed up through the Ipnavik thrust aheot as an overturned anticline.

(3) About 200 feet of thick-bododed black chert overlying ceveral hundied feet of black shale crops out in the foothills bordering the Delong Mountuing on tha north. Intrusives are absent and the atructure eppears to bo a series of curving inbricate thrusts.

\section{finor Iithulogic types}

On the headrators of the Fast Fork of the Kuna River, starata lithologically siniler to the Kiruktapiak nember are in gradational contact with the Kayak formation. At least 100 fect of crinoidal limestone crops out both north and south of the Delung dountains. On the westernmost headrater drainage of the lest Fork of the Killgwa Kiver a calcarenite or linestone conglomerate containing pelitic fraginents is faulted against the black chart-shale (section 3 aboro) unit.

The correlations of the above iajor units have not been established. Undoubtedly they are, in part, local veriations. wat Tailleur believes that, et Lt. Bupto, units 1,2 , and 3 (abovo) are largely lateral equivalents juxtaposod by thrusting. The facies distribution is interpreted to be limeatone to the north and blacis chert and shale to the south.

Post Lisburne, pre-Torok units.--An arkosj.c quartzose facies crops at sparadically teross the central part of the fuothills conplex. A aimlar facies has been found in the Nukg Hiver area. Formerly it was thought that these rocks represented the toprost stratu of the Lisburne forination (jississippian) 2/; howevar, nore recent paleontological atudy made by j. T. Dutro, indicatoa that they are more correctly re-

If Tailleur, I. L., Kent, B. 11., Stratigraphy and structure of the Suthern Fuothills eection between the Ftiviux and nilignu livers, U. S. Geulogical Survay Havy Vil unit irelili. Rept. W3, 1951.

2f Tailleur, I0 Lo, Kent, Bo Ho, Kaiser, H. No, Stratigraphy and structure of the Kiligwa liver area, Alaska: U. S. Geol. Survey Navy Uil Unit Preliu. lept. 37, 1951. 
ferred to the Pernian. Dutro proposer that the name Nuka formatkion be applied to them. A morthern gurce area for these sediments is indicated by an increasingly cuerser facies in that direction. The inuka formation was referred to the Permian aftor the map was drefted and 18 therefare not differentiated on the map fron the liaburne.

Littlo pertinent informetion has beon added to the descriptwons of the Siksikguk (Pernian), Shublik (Triassic), or Tiglukpuk (Jurassic) formations included in previcrus Navy Oit Unit reposts. Evidence of unconformities devel oped lccally bolow each of these units has been strengthened. The eatineted ruximais aggragete thicknss in the fuothilis complex is still 2,000 feet. The Siksikgak and Shubljk formations shoufd not thicken northwasd, but the effect of the Jurasgic on the total thickness is not kncwn. Becasse Jusassic (Tiglukpuls) sections.in the foothills are incomplete and varied, projected thickness eatimates of the Jurassic are highly speculative. Intra-Jurassic unconformities, ouggested in the foothills, may not be prosent to the north, with consequent thickoning of the eubsurfeco. Horever, the axis af deposition ney have baen along or south of the foothil18, and northward thinning would be expocted. A range of 1,500-2,000 feet of Jurasic beds, greater than the thicknese af controlled sections to the equth, is considered a reasonable estimate.

Okpikruar formation (Lotes cretaceous). - The interbedded sand-

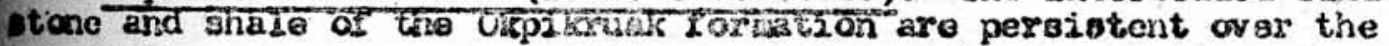
foothills and correlutive urits on tha Dalong thrusts aro sumilar. tht the varicolos-weatherisg ciay shale as the axis of the Bredy anthcline is dietinctily different. Not oncugh section is present thare to permit geroralizution, although the rapid change to shale mey be significant. If the observation that anny of the thick Bections of Okpthe ruak are rolated to thrust faul ts is valid, the facies gxadient may heve boen steepened by foreshortening. lithin the foothilla a rurked unconformity places basal beds of the okpikruak formation in cumiact with varions 0ldor units. Soue deformation preceded deposition of the Okpilaruak formation, although ito affect to the north cannot be determined. Becasse a northmard thickaning of the Ukpikruak is not expected, 2,000 feet is cunsidered its maximum nor:eal thickness on the Brady anticline.

Cestlo Mountain-Torok Lormations (Lower Cretacoous).-Patton 3/ he separaked the Toros lornation at the type sections into the lastle Yountain formation, an essontially coerse clastic southern unit, and the Torok formation, rarthern shale unit of wide distribution. He believes that the two units probably are tirse equivalonts but that this curralation is not conclusivoly establiahed.

The strata formerly cosignated Torok formetion in the Etivluk= Muka Rivers ares aro nos called lastj.e Mountain formation. Nu signiflcant thicknsese of vedo conparable to the loruk forration hare been recognised south of the Culvilile River. The shale underlyjing the lamashuk escarpment north of the Colville is probsbly correlative with the lorok formation.

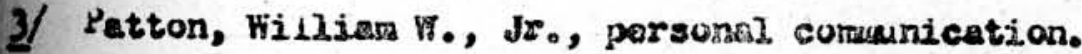


The Castle Mountain formation can be vorthiculdy subdivided into mo units. The $2000 \mathrm{r}$ unit consists of canglouszetic gxayvecke, quito leverely crumplad, that crogs out on Liborator lijdge, Mumumant Ridge, ind Smith Nountain, maginal to the Colvilze Rivar plein to the north. the upper part of this unit appesrontily grades northrard to interbedded Ippled sandstone and silty shale. The upper unit of heavy conglomerate orms Dkakevik and Swavback wounteins. No northerly equivalent has been bognized, but the conglonerate is assured to ahale northward. Capping leds on Ekakerik licunt in sab fine $\rightarrow$ greinad sardatone that reseubles the inal sandstone of the Namushuk group.

The base of the lower wnit at libarator Ridge overlies Shublik and lglukpuk strata. Outcrops of the Shublik formstion on either side of prument Ridge and its enstward extension suggost that the Ukpikruais I Tililukuk formaticas ase absent there also. Congloneretes of sharp fular fragments that appses to bo reworised rubble are locally charcteristic of the bassi becis.

Narth of the Liberacor Ridges beds bolleved to be part of the basal init are sandier than the overlying sequences. Actually, the oniy crkable tratsgraphic index in that erea is this zune of fine-gratned, rrk-gray, ripple-bodcod, yellowmred weathering sandstone in 6-inch to heot beds separated by noarly equal thicknesses of dark fissile clay hale or claystone. On the Ipravilk river, and to a lesser extent on the uligwa River, scattered aumonites and pelecypods occur in these strate. Ithough this zono coild well be a lithofacies that transects tive lines Ith migreting depositional emvironzent, available evidence places it in a bseal position in the Castle souniain stratigraphic sequence. ecause no horizon within. the Ukpikruak formation on the Brady anticline is positively identified by litholory or fussils, the character of the ontect between the Castile ucuntain and olpikruak formations i.s indeterinate.

1 The coarse clastics of the folded, zanrginal ridges (Liberator, etc.) Te broadly lenticular; individual becis parsigt only over short tis ences. The greographic distribution suggests deposition in restrictod tating.

A more restricted aspect is evident in the upper conglonerates if the Hikakevik isountain and Swayback jountein sqquencos. Both are derlein by uncouforaties representing 1,000-2,000 feet of masing lover unit. At Ekalievik Mountain, an initial sequance of shale grading prard to confl oxerate was depressed and then cruncated by a subse-

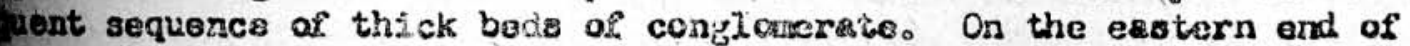
kakevik Hountain the thick canglonerates corolio pebble cunglonerates if the lower unit, whoreas on the western end, they overlie horizons 1thin the Okpikrsak formation. Approximatoly 1,500 feet of this thick onglomerate was weasured on the north front of Ekakevik iountain, but one is present on the south side. Apparenthy the sequence of congl ame wate was uplifted on the sasth side, truncated, and buried by nore pnelomeratic beds which salse up this mein iass of the present mountsin. his local dotijl is citod ss an example of the varlabie conditions inder which tho Cestle housstain furmation accumalatod. 
The thick conglomerates are conposed of subrounded chert and nafic abbles and cobbles with oceasional fregrents of liriestone. quartzits lecomes unore abundont towaxd the top of the cunglomerate. The sourca would have been an active thrust sheet of Lisbarne linestone and $\dot{i}_{6}$ neous ilis to the south.

The lack of intense folding of the upper unit can be explained by competency alone. Lor likaly, howevar, a partial axplanation is that daforming stresaes had waned by the cine tho upper unit ras deposited or that the upper unit, being younger, suffered fower pulses of the deformation.

Nanushuk group (Lower and Upper Cretaceous), molNo rocks of the Nanuthuk group aro prosent south of the Colville Hiver. But they extend pouth of the letitude of the Kiligwasksks Rivers baring (a provicassly secognised change in regional strilte) to the east and to the west. They were probably deposited ovor the area and since eroded. Soros elaatic zones within the Torok fcrmation appear to lie closer to the Penushuk group contact tharo woald be normal. if a basal pooition for the clastic zone is essumed. Lithar strong faulting or thinning of tha lorok by nondeposition or expeion is suggeeted. In splte af the observed radational contact betwes the llanushuk group and rorok formation on the Ilanks of structures, a reflection of the folding to the south ray have caused erosion or nondoposition over growing folds.

\section{STHUCTURS}

The tnost otrjking viructural features of the fuothills complex are the probable flat thrust cheeta composed of gonthy foldod Lisburne for antion and wafic 8il18. The Ipnavik sheet wes described in Kepgrt 43 is . and the Delong aheeta were mantioned in Preliminary Koport 37 s/. Although not all evidence oupports the hypothasis of 2argo-scale thrust faulting, it is assumed that flat thrust faults were a prinary element in the deformation of the foothills.

The Ipnavik aheet pasees northward into a complexly faulted series of ridges. Siniler feult zoidges of lisburne formation and diabese trend N. $60^{\circ}$ to $75^{\circ} \mathrm{W}$. across wach of the foothills area. They are not issociated with flat thrusts to the south but are in high-angle fault contact with the surrounding strate. Whether those ridges are related to flat thrusts, ejther as downofaut ted blocks of fosmorly more extenave sheots, ar as upofeulted blocks of subsurface thrusts, or whether they are related to other types of major structure cannot be determined. because they are daninent structural features, however, their presence long the southorn margin of the Castlo Hountain formetion exposures 13 significant ovidence of trong stresses active as far north as the roldod ridges.

The crimpling of the beds of the lower unit, Castle licuntian foration, in the folded ridges indicatas considerable north-eouth colopression but surface expression of larige-scale faults has not been recogrized.

Tailleur, Io Lo, and Kent, B. Ho, op cit.

Tailleur, I. Lo, Kent, $B_{0} H_{0}$, and Reiser, H. No, op cit. $-P-$ 
The doubly plunging synclines in which the upper unit of the Castle intain formation vecurs are folda of the same order as the broad Namak atructures to the north. Siulizas opon folda were imposed on the wot sheots and probably wora surgrimposed on the complex within the thills. The conclusion that stron comoressional stresses were not Tre after depasition of the upper wit of tha Casile Mountain forinaA Is not justified, although evidence of intense conpression of pate youniser than the lower unit of the Castle hountain formation is ding.

Structures underlying the plain nomth of the folded zidges are posed by the Ipnavik and Kiljgwa Ilivars. Crose sections (pl. .) of crops along the two rivers have boen prepared to shor the anount of cormation available and the degree of etructural cunjlexity developed. latteupt to show the atratigraphic order was ande on the Ipnavik fer cross section; the in'erpreted suratigraphic sequence is indicated inferred structurel traces on the Killigwa cross section. Several ars of folds nay be diaringuiehad or the cross sections, Ianging in the broad arch of the preaumed anticlinarium through Nanushuk-type on folds to minos cumplexities of orag folds. Analysis of the sketchy ta on the two rivers gives the inpression that not lanch of the Castle untain section observed in the fouthills is prasent under the plain.

All available jndicatioss of undexlying conditions wers utilized plotting the strike traces shown on the map. The Colville Hiver in io an erosional surface developed in fairly recent time. Draincunsequent to a lowered local bsse level, (rejuvenation of the iville liver), is not beconins subsequent as dissection of the higher face pruceeds. Linear divides and incipient trelije pattorns are oumed to reflect differential capetency of the underlying strata. plotted traces are, then, highily subjective and any derived conwaions are only as valid is the traces.

Several observations, though, uny be mide with some certainty. rficient perallelisin is exhibited by the traces to denonstrate a gional bowjing in the structural grain producing a northward bulge ross the Kiligwa-lika Rivors area. sroad undulations in the traces, condary to the inajor bowinf, are 21 so apparent. These would be very teresting if they are a reflection of underlying structure.

Convergence of the trends east of the Kilizgwa liver and east of the ha Hiver suggest an east plusho off the bowing. The density of the aces dinint.shes to the east. If the heavier traces actual. Iy represent (o loner paxt of the Castile Howntain formation, an easterly plunifo would ise less cuigretent (ycunger) staratia to be proserved on the eurface of a plain. "est plunje of the Brady antoj.cline is shown by measured thitudes on Uitten Creek. She traces to the west are not carried far ongh for a fair ovaluation of regiond west plunge. Photogreologic ps show gynclines in the Namushuk group plunging west frow the bowing a Sable 6 reports mare shaje on the western site of the arch than is pesent on the Kiligwa liver. Therafcre, indications of a gentle ghomal plune east and vest off the boring are fairly stran; The

Sable, Edward G., Dutaru, Jo To, and Hocriz, R. Ho, Stratigraphy and structure of the Drifforoud-Hoink aree, Hleska: U. S. Coul. Survey Prelin. Rept. 39, 1951. - 9- 
ces extending east from the Brady anticline project into the indedently determined structurgal high,on the Ipravik (alont the eastwing part of the river) 7f. Again, nothing definite may bo conded: The brady trand seems to be reflocted in tho heavy, arcuate ces just west of the Nuka River and south of the Colville River. ase traces cunverge at either and to indicato, if they are reflecgne of a structure, double plunge. Tho Nuke kiver lay rot transect, arafore, the otructure reprasentad by the traces. Horover, the ficture is afficientily interesting so werrant further study.

The Ayiyak anticlinoriun, as projected to Kucher Creek and the trluk Hiver, was traced on avajlable photos. It appears to project to the Carbon Creek anticline. 'the Kiligwa anticlinorium (brady) ild then be rolatad on echelon to the Ayiyaik high. The eustward jection of Driftwood anticline cuts the Kiligwa Kiver several miles th of the Brady anticline (photogeologic map $\mathrm{K}-17$ ). This en echelon ftern 18 duplicated by linear trands in the foothills cosplex, $\theta_{0} g_{0}$, fault ridges of the Lieburne formation and uafic sills.

A subject for further investigistion is the measurenent of the wave hoths (the distance between anticlinal creats) of Nanushuk group lds, the determination of the rats of change, and the southward papalation of this change to atterspt restoration of Nenushuk folds th the anticlinoriute. Restored Nanushuk folds wight coincide with arved surface structures and would be an aid in evaluating surface thures.

Of the many possible structura? eituations that the suriace inforthon will fith, we believe the three given belor are the najor alterthives to cunsidar:

(1) The anticlinoriuxs represents a brow arch of Lisburne fmation on which secondery and tertiary folds have been superingosed. is would be a typical anticlinorius and surface structures would reflect cse ut depths.

(2) The anticlinoriun represents a broad arch in the wisburne mation on which the less conpetent werlying beds have been crunulad a decollenent-type of folding. Surface structures would bo indendent of the basewent. 'Ihe apical aree of the arch could be deterhed only indixectly froin surface information. Similar cruspliting of sozolc strata cver undisturbed ladison linestone gn the west flank of 10 Sweetgrass arch in Montana has been doscribed 8.

(3) The enticlinoriun is a suparficial or nonexistent strucre that has resulted froil subsurface thrusting against or over a gional north dip. Surface structures might reflect structure on the rust plate but would be quite indepeadent of the structure below the urust.

Taillour, Io L., Kent, B. H., and Reiser, H. N., op cit. Vieswor, K. Jo, parsonal consunication. 
The first possibility would be hoped for but the least likely to our. The gruss simcilarities of the Southern Fuothills sectson to disturbed foothilis belt of the Alberta liveigy dountains justify interpretation that structures on the anticlinorium are reflections thrusts at depths (see (3) abore), analegous to penstrated strucres in Alberta. Consjidarable durbt of the validity of this interatation was caused by the flat basenent indicated at Castle Mountain seismic wark. No profesrod interprotation can be justified at sent. Additional field wor's probably will not resolve the problem; bourface conditions vili have to be deternined by goophysical means by drilling.

\section{The Brady anticline}

Uany references to the Kiligws River cross section (pl. I) will made in the following discussion and specific references wi ll be de to various field stations that are noted on the section directly 10i, the ourface data.

In the southern part of the cross section (KaOL to R27) there is over-all predoininance of south dips. The cross bedding and the valence of etrand mellirys of various types in the interbedded sandwo in this area ere believed to be valid criteria to deterinine the $p$ and bottom of the beds. Ihus it was concluded thut the strata own in this part of the crass section are, in general, not overturned 4 that station R27 is stratigraphically lower than station KlOL.

The microfossil sanples of this part vere barren and no macropsil localltios were found. No conclusive data are available to dicnte the age of the KIOL-1227 sequence relative to the stratigriphy the Castlo Mountain formation. However, an interesting coincince was noted: The strata at stations K16, K25, KR7, and K.26 conin aignificant amounts of pyrite, whereas rocks from stations south 106 du not contain noticeable anounts of pyrito. In his report on crofosils collegted in the Okpilcuak-Kiruktagiak Kivers area, 1949, k. Bergquist If mentioned that pyritized forms are characteriatic the laver part of the Castie Hountain furmation ('forok). Although melation of strata on the besis of contained pyrite is not justilable, the jyritifisrous nature of both the lithologic unit noted on - Kligwa Kiver and the lover part of the castle vountain farmation the Ukpikruak-Kiruktagiek hivers area may be contributory cvidence their currelative ago.

Station 117 was oxisinally believed to mark a structural high comse of an obsezved nujor southodipping reverse fault. The cornition of beds at $k 7$ is sinilar to that of the shale locally undering conglaneratic strats of the lover unit of the csatle uountain rmation in other areas. The hackly bedded shale with lime-eilt jórs and pyrite nodules is a distinct lithologle assemblegs.

Bergquist, H. Ro, personal ccusunication. 
At station $\mathrm{R} 27$, evjdence of faw.ting ant lithology dowinated by sile shale with thin intarbeds of red-weathering, fine-grained grayloke sandstone wore observad. These distinctive beds iny be correled with simil.ar beds on the flanks of the K22 (Brady) amicline.

Armonites were found at station $\mathrm{K2O}$, in the northern pary of the ses section (i.e., north of $68^{\circ} 55^{\prime} \mathrm{N}_{0}$ ). No positive identiflacation these fussils has been nade. Ausponite zones described elsewhere Je been linited to lower horizons of the Castle Hountain formation. rocks at station K2O do nut heve the shall 10N-water aspect comnon those to the south.

A fault marks the northem lizait of R2S where steep dips and rturhed beds are charactoristic. Station K21 shows a markedly ferent structure: swall, undulating, symmetrical folds with $30^{\circ}$ nk dips. The rocks at K21 are mich ccarser, strand markings are non, and yellow-weathering sandstono beds are prominent.

Rocks at station $R 29$ have a distinctive composition. The sand200 beds are massive, well - indurated, and cross-beddod. The color Iresh surfaces is dark gray but weethering produces a brownish red. bonsceous material and silt incilusions are abundant. Fissile black 1e (comprieing 50 paricent of the section) is interbedded with the datone. The structure 28 one of vary gentle $\left(5^{\circ}\right.$ to $\left.20^{\circ}\right)$ scath dipe, dually incressing northward to $50^{\circ} \mathrm{S}$. at station K22.

Strata on the south flank of K22 are fissile black shale ( $80-90$ cent) with intarbeds of evenly bodded, red-weathering, dark-gray datone. The north flank of the atructure at station $\mathrm{K22}$ repeats is sequence and dips $30^{\circ}$ north, but chevron folds are present.

The anticline thus outlined at atation K22 is the focal point of erest. Within a doninant lithology of black fissile clay shale (ean, black, yellow, and red weathering) on tho crestal part of the Icline, a 20-fuot zone of shell beds occurs. The shell beds are how brown and contain pelecypods in an excellent state of presertion.

The fossils were identified as Aucella sublaevis Ktyserling 10/ Velanginian age), a form that elsewhere is characteristic of the laruak formation. ificrosussil. sanples from the associatod shaleo barren.

The folloring broad atructural interpretation is bolieved to be tantially correct to this point: the fossil determination and unalysis of the exposure to the south indicate a structural high fitation K22. Fron station R27 to K23, strata believed to be the ver unit of the Castle kountain forration indicate that not a great atteraphic thickness is involved.

The relative subeurface position of the Okpikruak formation in the is of courso speculative and the positions of ulder formations are mare 80. If the aequence is narnal, the lisburne formation should present about 4,000 feet belor the structural high at station K22.

Imlay, Halph ho, personal cumsunicetion. -12 - 
Strats on the north slank of the structural high (K22) du not relate very well with those on the soush flank. The atrata at tion K24, K25, and $R 30$ cannot bo assigned with assurance to any atigraphic position within the Castle Muuntain formation. None the criteria of the lowar unit apply, and contredictory interpreIans are possible frore what littie sactual data is at hand.

The only fossil found is an unidentified pelecypod fregment in matrix of a zone of coarse-irained rocks at station 1230 . Wicrosil samples were barren.

At station K2L steeply dipping overturned shals and sandetune are foult contact to the north with a gently dipping $\left(15^{\circ} \mathrm{N}\right.$.) section assive sandstone. A short distance to the narth this section also ames cremulated and overturned ( $70^{\circ} \mathrm{S}$. dips in the overturnad beds). sandstone is light gray green on fresh surfaces and contains carceous material and silt inclusions. They are unch "cleaner" in farance than the sandstones south of the K22 high.

The rocks at station $\times 25$ cunsist of light neutral green sandstones rbadded with darker gxay shales. The sandstones are ripple-roarked cruss-ledded; there is scase tendency to lemination. A northeast ike here contrasts to the ayproximate N. $80^{\circ}$. llent to the south. Folds are gentle to intense.

The beds at station $\mathrm{R} 30$ sirike esst and dip $65^{\circ} \mathrm{N}$. A $20-$ foot of confloneratic beds is present. The pebbles include black, b. and green chort, and white quertz. Yobble oise averages a quarter in inch in dieneter. Silt inclusiuns are larger ( 1 to 6 inches in eter). Similar peuble sujtes are curmon in cunflomeratic beds hil throughout the Castle kountein formation.

At station $\mathrm{K} 2 \mathrm{~L}$ a feult separates beds of uarkedly different conthon. The rocks at stetion $K 23$ reseinble those on the flanks of structure at station K22. Also from $K 23$ to $\mathbf{K} 24$ more intensively med beds were noted. The rucks at $k 24$ (north of the fault) and we lithologically similns to strats elsewhere cunsidered to be Aigraphically higher in the furmation. For this reason and in Sderation of the orer-a,d. structural information available, a thetical fault was drawn betwcen $K 23$ and K24. The line of reasonand interprotation would thon follow patterns established for tho iilis of Alberta.

However valid such an interpretation may be, the following interption appears to be equaliy velid:

(1) Facies changes are pronuunced in the Castile Mountain ation. The formition shales to the north.

(2) A basel clastic tongue of Castle dountain atrata extends hured. 
(3) Hegardless of the appearance of the strata at stations 125, and 1230 they repreaent sections of taixly coarge elastics orms of grain siza and parcont of shale.

(4) Facies charges in charactoristics other than grain size th be predicted across the crest of the structural high.

(5) The northexn sectigns way be correlative fwith minor s) with sections at stritions $\mathrm{K} 28, \mathrm{~K} 2 \mathrm{O}, \mathrm{H} 28$, or K21, completing the of the indicated siructural high. The strata of the north limb in no appreciable amount of pyrite, but that may be the significent, orence. However, pyrite neither proves nor disprovos such a correan.

In an over-all avaluation of possible drill sitis the location feet or so south of K22 vas proposed for the following reasuns:

(1) If the indicated siructure is simple, such a drill site d reach the Mississippian at moderate dopth and should not be too lown the n.ank. The site would be near the oldest strata known se surface.

(2) If the otructure is conplex, the proposed well should sect a sigrificant fault and valuable stratigraphic information obtained frum both sides of the fault plane. From more preciso matical calculations it was concluded that lississippian strata be reached before such a fault plane would be cut, but the fault would lie at driliable depth. These calculations vere based on Tyeis of producing rells in the Alberta foothills fields. Average as were obtsined between the horigontal distance south of a surface ) and the vertical depth to a pay zone. I'he estinated depth of disourne formation and the curvature of the hypothetical fault with curface location detarnined by the average ratio resulted in this usion.

The indicated structural. high at station $\mathrm{K} 20$ should be mentioned. based on the occurrence of ausmonites which are not specifically sfied; the attitude of tho beds is nearly vertical but anticlinal 3 are indicated at some distance buth north and south of K2O. general stratigraphic and stiructural control is inadequate, but Indications as are present morit inure dotailed inspaction as a ble future drill aste. At the present time the drill site at Ion 122 is favored because such a site would more edequately test ubsurface characteristics of the ares; mare pertinent stratsIle information would be gained, and the "ecunomic potantidl" is equal at both sites or Blightiy in favor of the drill site at lear) K22.

\section{OIL POTENTIALITIES}

Turable petroleum indications were noted: (1) asphaltic 20 in porous dolonite on the ridges of Lisburme forination; (2) Wiy bituninous character of the shale and linostane; (3) esphalt In deforwed beds; (4) positive oil cuts frors some specimens of 
Nuka (quartzose) fornation; and (5) strong oil cuts from Jurassic istone cut by a foult zone that apparentiy intarsects the Lisburne ation at shallow depthis.

The Lisburns Iinestone in the southern foothills probably accum-

ad under geosynclinal conditions. An expected northward change to

f environment might cccur very rapidly, comparable to the rapid

ard thinning of the lissiseippian in Alberta. Huvever, we infer

the Lisburne in a favoreble facies would normally be present

the brady anticiline.

\section{RECOLNENDATIONS}

Seismc profiles believed nocessary to adsquately prospect the we-Nuka Rivers boring are shom on the nap. Also shown are the proposed by C. Lo Uohr. Our profile across the Brady structure ile i) practically coincides with Lohr's. Assuming that this long rields no positive results, Hohr's line along the Kiligwa would tu have less pronize then our lines to the west (profiles 2 and 3). pinted out above, the apsx of the bowing is west of the Kiligwa At least one of the western profiles should be run to conduct gmostic test of the eree. "ithout it, we boliove the preliminary attion of the bowing would be inadequate. If a reversal at depth - the brady anticline is found, the eastern profile should be run lat east plunge. Profile 3 would test west plunge. In any case, lang line (1) fron Lookout liidge to the vicinity of Liberator Laike cential for the broader outlines of the anticlinorium. North of olville hiver it will cross a possible structure that nay prove fosting. If any conciusions are gained, a similar line might bo ded north frun profile 2.

Of course, if the Brady location is tu be drilled as a strati-

ic test regardless of seismic results, the lines have to be con-

yed from the viewpoint that the most possible local sources of mation should be tested. The coveraje shuin $b_{j}$ ilohr's shorter and our profiles would then be required. However, any reevalua. of the subsurface subsequent to completion of a well would require inst one line to the rest.

It 10 ouggested that the Triassic (limestone)-Jurasaic (shale) ot uf ght be an additional reflecting horizon. It should occur in 600-1,000 feet above the top of the liaburno.

Wie lso recomend that 5- to 10-pound bottom-hole samples bo cted along the profiles. In the case of sandstone samples, the logy may be correlated with lithologies on the river: in the case 10 samples, a largo, relatively unrosthered sample may yield cossils. Withough inicrofossils are rare in cutcrop, caraful uating of hirge saraples nay be uare profitable.

It seems advisable thet either Tailleur or Kent be available to s In the interpretation and eveluation of the seismic returns. our cun be in fajrbanks ebout llarch 1 for that purpose. 
A field party has been proposod to inap in detail the exposures in io area of the bowing. Seismic results way be dofinitive and theroby piate surface investigation. In the event thet the geophysical work inconclugive and a woll location wast Btill be made, a detailed reface ourvey will bo necensary. We are not optimistic about the robable rasults of more lieid mappirag. Glose mapping of the cutbanks dintor-strean traces should affond the basis for a statistical analysis the structures. Dstajled loiging of surface sections should give a ther understanding of the stratigraphic sequence and intorprotations rod on strati.graphy rould be sounder. A study of the exposures and aces north af the Colvilie Kiver to lookcut Kidge offers soine promise pertinent information.

PHOTCCEOLOCIC OBSFRVAFIONS ON THE BRADY' ANITCLTHE

By iillitiass A. Fischer

A study of the aerial photographs of the Brady anticline in the loinity of the Kiligwa Kiver yields little informetion not thoroughly vered in Special Report 40 . Some of the observations strengthen the ructural interpretations it. presonts.

\section{Stratugraphy}

The aerial photoyaphs yield little stratisraphic information; wever, it is evident that the area is une largely covered by rucks fich puorly rosist the effacts of wanthering, (probably largely shale). (2) surface appears slightly more "jaottled" along the trend of the fady "anticline", this may ropresent a slight change in lithulogy may be due to a locil. atructural condition, such as tight folding id minor faulting.

\section{Structure}

Three possible structural interpretations can be made from the the visible on the aerial photographs. Ihe fixst, that of a narinal ticline or anticlinoriun, io supported by the apparent convergence ("traces" innediataly east of the Kiligwa Hiver. The greater conirgence is on tho north 2irab. 'Shis cuuld be due to faulting. The fotogeologic studies indicate a slightly greater convergence than bat indicated on Plate 1, Special Report 40.

The socond intorprotation, that of a strike fault (possibly an (erthrust) is strongly supporied by an almost startling alignment of ratnage features along the supposed trend of the enticlinorium. milar alignentos occur soutin of the "2xis" and a comperison of the pition of these features to the pesition of faults shown on the joss section, Special leport 40, Plate 1, shows a near parfect correthen. It is interesting to note that the course of the Colville viver approximstely lis wiles north of the "exis" of the Brady ant1ine is parallel to the alignment of the dralnage features and faults ith of the axie. 
The third structural. interpretation is based on rogicnal and $2.0 \mathrm{ca}$ ? consideretions and dete. This interpretation is favored by the author. The four wain parts of this interpretetion are:

1. That the Brady "anticline" is at depth a high angle strike fault; upthrom on the sourth.

2. that the south limb or upthrown block is cut by several thrust feults of minor displacement. Southward from the "exis" each pocessive fault has a shallower angle of thrust.

3. That displecersent on the high angle fault incressed ling deposition of the sorok formation resulting in the doposition a much thicker section of Torok narth of the fault.

4. That the sain fault trend contimues to the east and west the kiligwa Kiver for isany wiles, probably in an en echel on arrangethe

U. S. Geological Survey OPEN FILE REPORT

This report is preliminary and has

not been edited or reviewed for conformity with Geological Survey standards or nomenclature, 